\title{
Research on Aesthetic Culture and Artistic Communication in Frontier Minority Areas under the Background of "the Belt and Road"*
}

\author{
Zheng Chen \\ Faculty of Humanities and Social Sciences \\ Dalian University of Technology \\ Dalian, China
}

\author{
Hai Liang \\ Faculty of Humanities and Social Sciences \\ Dalian University of Technology \\ Dalian, China
}

\begin{abstract}
With its special location advantage, the frontier minority regions become an important bridge connecting the inner and outer parts of the region. The spread of regional aesthetic culture and art is an important breakthrough point for constructing cultural exchanges with neighboring countries along the border and driving the people's hearts to communicate with each other. We should base on the multiple media environment in the contemporary frontier minority areas to analyze the multidimensional attribution of aesthetic culture and artistic dissemination aiming at complex spreading forms, put forward the idea of adhering to the concept of "harmony in diversity", strengthen the confidence for aesthetic culture of the participants, regulate and control the orderly development of aesthetic culture and artistic communication, and provide an effective way to improve the aesthetic culture and artistic communication power in frontier minority areas and achieve the cultural advance of "the Belt and Road" by integrating communication resources, innovating communication paths and optimizing communication ability.
\end{abstract}

Keywords-the Belt and Road; frontier minority areas; aesthetic culture; artistic communication; media

\section{INTRODUCTION}

The ancient Silk Road stretched for thousands of miles and lasted for thousands of years, which not only brought the prosperity of trade and commerce, but also brought extensive and frequent cross-regional exchanges of national arts and culture, and promoted and developed the blending of different civilizations. Both for the historical research of the ancient Silk Road and the co-discussion, co-construction and co-sharing emphasized by today's "the Belt and Road", cultural dimension is indispensable. The integration and support of artistic forces plays an important role in promoting cultural advance, deepening cultural exchanges, and driving the communication between people. Frontier minority areas have various artistic forms with rich connotations, distinctive features and a wide range of influence, which not only bear the outstanding Chinese civilization, but also have strong artistic and cultural identity with neighboring countries along the border. Its communication and exchange can strengthen the cultural

*Fund Project: This paper is a phased research result of the National Social Science Fund Project (14BZW124). thickness and value of the "the Belt and Road" strategy inside, and can strengthen the dialogue with different civilizations in other countries outside to promote the symbiosis and co-prosperity among cultures and build the psychological foundation of economic cooperation.

Hegel divides the elements of beauty into two kinds, one is internal, namely content, and the other is external, referring to those with which content shows its meaning and features. [1]The communication is the most important form for the preservation and development of aesthetic culture and artistic form. On the one hand, it is the inheritance of symbolic material form. On the other hand, it is the transmission of spirit. [2]In the contemporary communication, the multiple media environment is formed by interpersonal communication, mass communication and network communication, which includes not only the communication of artistic content, but also the transmission of implication and features beyond the content. The aesthetic interaction between the recipient and communicator is formed by means of media form and communication technology. The multiple media environment in the frontier minority areas has brought the extremely complex influence and many opportunities for the aesthetic culture and the artistic dissemination. Aesthetic culture and the artistic form close to the origin make the frontier minority areas and "the Belt and Road" along the neighboring countries form a certain cultural integration in the early historical interaction, and has some common cultural psychological basis [3]. This has constructed a good platform for the artistic communication of the frontier minority areas under the background of "the Belt and Road" strategy. However, the multiple media environment also brings about the complex characteristics of art communication. It is necessary to integrate aesthetic culture and art communication in an open and pluralistic communication system with multidimensional attribution and path innovation so as to realize cultural advance. 


\section{ADHERING TO THE CONCEPT OF "HARMONY IN DiVERSITY" TO PROMOTE THE MUTUAL EXISTENCE OF AESTHETIC CUlture}

The plurality, heterogeneity and complexity of Chinese aesthetic culture itself determine the aesthetic cultural exchange idea of "harmony in diversity" with the related countries of "the Belt and Road", which has also become the guiding concept of art communication in the contemporary frontier minority areas. In the open and pluralistic media communication system, the communicator and the receiver, as the elements of communication, become the main node of the flow of the concrete symbols of aesthetic culture and art forms in the communication structure. Among them, the communicator has a great initiative in the aesthetic cultural dissemination, and plays a vital role in the dissemination effect. The recipient, as the object of art communication, is the key to the acceptance, absorption and re-dissemination of aesthetics through the interpretation of the information conveyed by the transmitter, as well as the understanding of aesthetic culture and art form. However, the individual or the organization, either as a communicator or a recipient, the natural geographical environment in which it is situated, its ethnic structure, social level, and artistic accomplishment all have heterogeneity. At the same time, in the course of communication, the choice of different channels of communication, the application of communication technology and the encoding of communication content promote the appearance of aesthetic culture and art forms in different regions. In the process of individual collection and information processing for aesthetic cultural communication, the individual or organization has differences in aesthetic understanding, grasp of the principle of media production, and their own aesthetic concepts. The heterogeneity of these communication elements has become the main factor of artistic communication, fusion and game in the communication of aesthetic culture of "the Belt and Road".

In the communication of aesthetic culture and art in the contemporary frontier minority areas, we should first face up to and respect the rationality and objectivity of the existence of aesthetic heterogeneity in the source of communication, but we should also pay attention to the problem of no exchange of information between the transmitter and the recipient, or shortened cycle of information vitality caused by such heterogeneous communication. Therefore, the use of new media techniques has become the key to solve the problem of the heterogeneity of aesthetic culture, such as the use of social media. Social media is the development and extension of Web 2.0 application. It is a new network media with more people participating actively, sharing collectively and integrating people's real social relations. [4]In social media, the communication participants are more connected by the network and spread and feedback the information through the interpersonal communication. Users have the characteristic of homogeneity. This feature of communication structure, coupled with the intuition of aesthetic culture itself, makes it easier for the recipient to identify with the communicator's artistic communication behavior and arouse his inner regional emotion to strengthen the acceptance and recognition of artistic communication and arouse the willingness to absorb and forward. At the same time, the recipients are more willing to evaluate and judge the content of the acquired information according to their personal consciousness and cognitive system, their own social communication circles, and their credibility and dependence on the "opinion leaders". This attribution and the aesthetic culture and artistic communication constructed through reproduction and migration of people in early natural and geo-ecological space form a coupling, which also further illustrates that social network communication achieves the return of real interpersonal relationships. According to Six Degrees of Separation, social media as a new type of network media further break the limitation of time and space. The homogeneous communication constructs the important communication path for the heterogeneity communication of aesthetic culture and art, and its sharing communication with recommendation effect and the chain communication with strengthening effect [5] can make the aesthetic culture form the spiral diffusion, to promote the artistic communication force and form the communication innovation.

Comrade Xi Jinping pointed out that it is necessary to build the "the Belt and Road" into a road of civilization. The construction of "the Belt and Road" should transcend the estrangement of civilizations with the exchange of civilizations, transcend the conflict of civilizations with mutual learning of civilizations and transcend the superiority of civilization with coexistence of civilizations to promote mutual understanding, mutual respect and mutual trust among countries. With its openness and tolerance to heterogeneity, the new network media provides an effective way for aesthetic culture and artistic communication in frontier minority areas, and it also becomes an important embodiment of the idea of "harmony in diversity" in cultural exchange.

\section{CONFIRMING THE AESTHETIC CULTURAL CONFIDENCE OF PARTICIPANTS AND ENHANCING CULTURAL INCLUSION AND MUTUAL TRUST}

Cultural self-confidence is a state gradually formed in the process of cultural development, as well as [6] more basic, more extensive and deeper self-confidence. It is also the foundation of China going to the world and embracing the world civilization. The strategic framework of the consciousness of cultural community with openness and inclusiveness as the core connotation that is advocated by "the Belt and Road" is not only the manifestation of aesthetic cultural self-confidence, but also the embodiment of aesthetic cultural mutual trust. Frontier minority area as the hub of foreign exchanges of "the Belt and Road" should rely on the advantage of aesthetic cultural advance. We should not only stick to our own cultural mission, cultural rights and cultural responsibilities, spread the aesthetic values of contemporary China extensively, and show the unique insights and charm of regional art, but also form embedded interaction with the aesthetic culture of other countries or regions, expand the field of humanities and art exchange, and exert the function of the cultural energy and significance.

In the open and multiple media communication system of contemporary frontier minority areas, there are multi-level 
and heterogeneous communicators and recipients. Firstly, different communication participants have diverse and complex motivation demands. For example, when communicators encode the information of aesthetic culture and artistic communication content, they are not only influenced by such factors as communication motivation, profit motivation and individual achievement motivation, but also mixed with the adaptation to the specific situation of the times and society and acculturation psychology. For another example, the recipients of receipt and decoding of the information of the regional aesthetic culture mainly originated from the psychology of demand, emotion, and reason and so on, and also influenced by the attention of oneself, the opinion leader and the individual's impression of the regional aesthetic culture and the cognition of the dissemination effect and so on. All of these have become the key motivational factors for the communication participants to encode, decode, absorb, modify and communicate the information twice. On this basis, diverse motives have brought about diverse communication organizational behaviors, including a variety of communication perspectives, communication methods, communication channels, as well as the types of viewpoints in the communication, and the organization of viewpoints and so on. Therefore, in the regional aesthetic culture and art communication composed of complex factors, the insufficiency of cultural self-consciousness and the lack of cultural self-confidence will lead to the improper motivation and behavior of the communication participants, such as the dislocation of the agenda setting function of the traditional media communication, the failure of the wind vane of the mainstream media, the inability of the communication without publicity, and the chaos of the aesthetic culture and art communication of going with the tide and failing in distinguishing right and wrong in the network media. In the aesthetic culture and artistic communication in the contemporary frontier minority areas under the Background of "the Belt and Road", the lack of cultural self-confidence may also lead to the loss of the essence and uniqueness of the aesthetic culture of the country, the region and the nation in the cultural exchanges with different civilizations, and even the continuous alienation, which not only affects the inheritance, development and innovation of the regional aesthetic culture, but also causes the difficulty in the exchange and dissemination of the artistic culture with other countries.

Therefore, it is the core prerequisite to strengthen the cultural tolerance and mutual trust of "the Belt and Road" to firmly spread the aesthetic cultural self-confidence of the participants. In the cultural communication of frontier ethnic regions, the aesthetic cultural self-confidence of communication participants is mainly embodied in the activities of communication, such as the values of regional aesthetic culture, excellent artistic tradition and artistic system, aesthetic symbols, and the encoding, deconstruction and re-dissemination of daily life aesthetics. Participants spreading aesthetic culture and artistic forms in frontier minority areas with a more self-conscious and confident attitude towards aesthetic culture is not only a full affirmation of the value of one's own culture, but also an important guarantee for "co-discussion, co-construction and co-sharing" under the background of "the Belt and Road". It is the essential embodiment of Mr. Fei Xiaotong's cultural relations of "praise their own beauty and praise other's beauty so that different beauties co-exist and harmony of the world can be achieved".

\section{GUIDING THE ORDERLY DEVELOPMENT OF Aesthetic CUlture AND ARTISTIC COMMUNICATION TO PROMOTE THE SOFT POWER OF CUlTuRE}

"The Belt and Road" is not only a spatial concept and economic cooperation strategy, but also a cultural influence category based on the influence of historical and cultural concepts. It is a strategic framework that links history, reality and the future with culture for China to face globalization. [7]Therefore, the display and call of cultural soft power has become the main focus of the cultural dimension of "the Belt and Road". The dissemination of aesthetic culture and art in the frontier minority areas is of great significance to the promotion of the cultural soft power of China and the expansion of cultural influence, radiant force and inspiration. The healthy, rational and orderly development of aesthetic culture is the basis of cultural communication. However, the open communication environment, multiple communication media and multi-level communication participants in frontier minority areas make the communication elements and influence factors have complexity and relevance. The communication of aesthetic culture and art is a complex, interactive and dynamic cooperation and game of multiple communication subsystems. At the same time, the technical forces lead to great changes in the ecological environment of the media, the production mode of traditional media is transforming relying on the Internet, and the divergent dissemination of network media has also brought many problems. In the so-called "decentralized" new media ecology constructed by the Internet, it is necessary to consider how to ensure the orderly and sound operation of the media science and technology platform system. [8]This is also an important guarantee for aesthetic culture and artistic communication.

In the current media system, the transmitter and the recipient gradually realize the role transformation, mutual recognition, and gradually equal status and rights. There is a complex interaction relationship between nodes. Participants spontaneously form information dissemination behavior and coordinate to automatically form an ordered structure through a certain tacit agreement with each other, which is characterized by the emergence and self-organizing characteristics, namely the unique self-organizing characteristics, conditions, environment and dynamics law of the media dissemination system [9] However, at the same time, it is found that, the flow pattern of regional aesthetic culture and artistic form in the Media communication system is not entirely self-organizing, equal, mutual assistant, and multidirectional communication. The content of flowing information not only is "universal, standard and decontextualized", but also implies the influence of the communicator, the recipient and the media's own "production rules, interests, and power relations". That is, in 
the self-organizing phenomenon of aesthetic cultural dissemination in frontier minority areas, there are other organization behaviors which are influenced by external factors such as social environment, political environment, cultural environment, economic environment, public consciousness and economic interests. These communication behaviors formed by relevant interest groups make the information content of regional aesthetic culture multipolarization, and there are potential communication risks such as "alienation" of aesthetic cultural understanding.

To ensure the healthy, orderly and sound communication of aesthetic culture in frontier minority areas, it is necessary to give full play to the function of reasonable regulation and control of media communication by functional departments. From the macro-level, we should respect the communication law of different media and adhere to the mainstream ideology and value orientation of mass aesthetic culture. And through the accumulation and communication of aesthetic culture and artistic cultural value, we can promote the formation of the common psychological characteristics of the communication participants and enhance the identity and stability of the group. From the medium level, we should coordinate and integrate the multi-media communication, play the mainstay role of traditional media aesthetic culture and art communication, and supplement the strength of aesthetic culture and art communication through the network media. From the microcosmic level, we need to grasp the characteristics of "self-organizing" of communication elements, intervene in the communication agenda precisely at the right time, and guide the mass aesthetic cultural communication. It is also necessary to correctly cope with the intervening role of "other organization" in aesthetic culture and art communication in frontier minority areas, make use of its positive communication behavior to further promote regional aesthetic culture and art communication, form mutual promotion with "self-organization" communication mode, and discover negative aspects in time to eliminate potential adverse effects. The implementation of this series of strategies is an important guarantee to optimize the communication function of aesthetic culture and art in frontier minority areas and promote the strength and influence of regional aesthetic culture, as well as an important measure to realize the promotion of cultural soft power under the strategy of "the Belt and Road".

\section{CONCLUSION}

In May 2017, Comrade Xi Jinping, at the opening ceremony of "the Belt and Road" International Cooperation Summit Forum, pointed out that the "Belt and Road" should be built into a road of civilization. The construction of "the Belt and Road" should transcend the estrangement of civilizations with the exchange of civilizations, transcend the conflict of civilizations with mutual learning of civilizations and transcend the superiority of civilization with coexistence of civilizations to promote mutual understanding, mutual respect and mutual trust among countries. Aesthetic culture and artistic communication in frontier minority areas is an important way to promote communication and exchange among different cultures. It is also an important entry point to tamp the basis of public opinion for cooperation with the neighboring countries along "the Belt and Road" and realize the communication of the people. We should further exert the multiple advantages through integrating communication resources, innovating communication paths, optimizing communication ability to focus on the strategy of "the Belt and Road" in promoting the external spread of regional aesthetic culture and art, expanding the external influence of culture in frontier minority areas, and playing an important role in the connection of "the Belt and Road" cultural ties and cultural space.

\section{REFERENCES}

[1] Hegel: Aesthetics, vol. 1, Commercial Press, 1982, p. 25.黑格尔: 《美学》第 1 卷, 商务印书馆, 1982 年版, 第 25 页。

[2] (American) Susan, Langer, Gao Yanping, Translated. Feeling and Form. Nanjing: Jiangsu People's Publishing House, 2013, p. 409.[美] 苏珊, 朗格著, 高艳萍译: 《感受与形式》, 南京: 江苏人民出 版社 2013 年版，第 409 页。

[3] Zhao Chengcheng, "Cross-cultural Communication Strategies in the View of "the Belt and Road ", Media Today, No. 2, 2016, pp. 155 157. 赵澄澄《“一带一路”视域下的跨文化传播策略》, 《今传 媒》,2016 年第 2 期, 第 155-157 页。

[4] Liu Xingfang. Introduction to New Media, Beijing: Communication University of China Press, 2015, p. 152.刘行芳《新媒体概论》北 京: 中国传媒大学出版社,2015 年,第 152 页.

[5] Lu Xiaohua. Reflection on the Transformation of Communication in the New Era", News Front, No. 4, 2013,pp. 81-82.陆小华《新时期 传播转型的思考》，《新闻战线》，2013 年第 4 期, 第 81-82 页,

[6] Chang Yanhui, Song Jianlin. "On the Cultural Confidence of the People Stemming from Cultural Construction", "Party Building and Ideological Education in Schools", No. 13, 2016, pp. 37-40.常宴会、 宋健林《论人民的文化自信来源于文化建设》, 《学校党建与思 想教育》，2016年第 13 期，第 37-40 页。

[7] Kui Binxian. Strategy and Countermeasure of Cultural Communication and Exchange under the Background of "the Belt and Road", Zhejiang Academic Journal, No. 2, 2016, pp. 214-219.隗斌贤 《“一带一路”背景下文化传播与交流合作战略及其对策》，《浙 江学刊》, 2016 年第 2 期, 第 214-219 页。

[8] Tong Qingyan. The Future Development Trends and Reform Strategies of Chinese Media, People's Tribune, No. 23, 2016, pp. 32 35. 童清艳《中国媒体未来发展趋势与改革策略》，《人民论 坛》, 2016 年第 23 期，第 32-35 页。

[9] Oka, M., Hashimoto, Y., \& Ikegami, T. (2014). Self-organization on social media: endo-exo bursts and baseline fluctuations. Computer Science,9(10), e109293-e109293. 